\section{CARTA DO LEITOR}

\section{Ao Editor}

Tenho a satisfação de passar às suas mãos uma cópia da série de documentos que acabo de receber de parte do Doutor Bernard Lown, professor de Cardiologia da Faculdade de Medicina da Universidade de Harvard, relativos a uma reunião de caráter internacional que se realizou de 3 a 8 de abril deste ano, em Cambridge, Inglaterra, promovida por profissionais que atuam no vasto campo da medicina em países do hemisfério norte, com o objetivo de submeter a amplo debate, no plano estritamente médico, as conseqüências de eventual deflagração de uma guerra nuclear na Europa. Foi a segunda vez que a referida organização, criada nos Estados Unidos da América, em 1980, sob o título "Internacional Physicians for the Prevention of Nuclear War" (IPPNW), reuniu-se para um intercâmbio de idéias sobre a terrível ameaça para a saúde individual e coletiva, de um holocausto nuclear.

Em dramática declaração, aprovada em seu primeiro Congresso, realizado em Airlie, Virginia, de 20 a 25 de março de 1981, a IPPNW já deixara bem claro que, na eventualidade de um bombardeio nuclear, praticamente nenhum socorro médico poderá ser oferecido aos poucos sobreviventes da área devastada. De fato, a bomba de apenas treze quilotons que destruiu Hiroshima, matando instantaneamente um terço de sua população de duzentos e cinqüenta mil habitantes, ferindo mais de cem mil pessoas e destruindo noventa por cento dos edifícios (aí incluídos quarenta e dois dos quarenta e cinco hospitais ali existentes), nada hoje representa face à terrível realidade que a Organização das Nações Unidas vem de revelar no número 17 da publicação "Notas Descritivas do Desarmamento", ao referir-se a um relatório do Secretário Geral (documento das Nações Unidas A/35/392) que informa:

- é provável que existam atualmente no mundo mais de quarenta mil ogivas nucleares;
- a potência total dessas ogivas pode ser eqüivalente a cerca de um milhão de bombas como a de Hiroshima, isto é, para cada homem, mulher ou criança deste planeta há mais de três toneladas de TNT;

- o tempo de vôo de um projétil balístico intercontinental com base terrestre, desde o lançamento até alcançar seu objetivo, é de mais ou menos 30 minutos. Se o projétil for lançado de um submarino, o tempo de vôo será ainda menor. Assim, por precoce que seja o sinal de alerta, impossível será evacuar as populações das cidades-alvo;

- a explosão de uma única bomba com a potência de um megaton em uma cidade de quatro milhões de habitantes (como Detroit, ou Leningrado), teria os seguintes efeitos: em Detroit quinhentas mil pessoas morreriam imediatamente e seiscentas mil ficariam seriamente feridas; em Leningrado, devido à diferente distribuição da população, as cifras seriam de aproximadamente o dobro. A zona de destruição de edifícios superaria $300 \mathrm{~km}^{2}$; as queimaduras e lesões produzidas por irradiação seriam enormes.

Esta gravíssima situação foi, aliás, objeto de uma reunião especial, nos dias 7 e 8 de outubro de 1981, em sua sede no Vaticano, da Academia Pontifícia de Ciências que, sob a Presidência do eminente cientista patrício, Professor Carlos Chagas FO, resolveu formular uma extraordinária e oportuna "Declaração sobre as Conseqüências do Emprego das Armas Nucleares". Após ter sido entregue aos Chefes de Estado da França, Grã-Bretanha, União Soviética e Estados Unidos da América, bem como ao secretário Geral da ONU, por comissões de membros da Academia especialmente designados pelo Santo Padre, a Declaração teve ampla divulgação em todo o mundo. Ao proclamar que uma guerra nuclear causará morte, doença e sofrimento em escala 
gigantesca, a Declaração também ressaltou a impotência da medicina ante tal tipo de catástrofe, insistindo que só uma ação direta de sensibilização da consciência universal dos homens poderá evitá-la. Termina por um apelo: "Si nous ne parlons pas, nous risquons de nous trahir nous-mêmes, nous risquons de trahir notre civilization".

O segundo Congresso da IPPNW veio dar prosseguimento ao movimento cada vez mais poderoso de gradual conscientização da humanidade contra a guerra nuclear. Viu-se, aliás, em Cambridge, que uma grande proporção de cientistas dos países mais desenvolvidos devota-se à produção e ao aperfeiçoamento das armas nucleares. Constatou-se, por outro lado, que em virtude de estarem praticamente ausentes desse campo de atividades, em nada contribuindo, portanto, para isso, os profissionais do campo da medicina desfrutam de ímpar condição de, meIhor do que ninguém, pode falar sobre paz. Realmente, seus conhecimentos especializados sobre saúde e doença, em seus mais diversos aspectos, dão-Ihes uma visão nesse terreno bem mais clara que a de qualquer outro grupo profissional. Além disso, cabe sem dúvida à medicina, por seus conhecimentos especializados em matéria de saúde mental, desvelar, senão denunciar a verdadeira paranóia coletiva que está provocando a presente corrida nuclear. Poderá, porém, a medicina curar aqueles que dela sofrem?

Todas estas considerações decorrem do fato de haver eu aproveitado uma breve reunião do Conselho Executivo da Organização Mundial de
Saúde, da qual faço parte, para tomar alguns dias de férias e, em companhia de um pequeno grupo de médicos latino-americanos (Marcel Roche, da Venezuela; Carlos Monge, do Peru; H. Hoecker, do Chile), convidado pela Comissão Organizadora do segundo Congresso da IPPNW, ao mesmo comparecer como observador. Pude, assim, acompanhar não só as discussões de seus onze grupos de trabalho sobre temas específicos, como os dramáticos debates das sessões plenárias. Tanta impressão me causaram que resolvi transmitir o respectivo registro à entidade que congrega os educadores médicos e as escolas de medicina deste País. É assunto candente que precisa ser conhecido, tanto por nossos colegas, quanto pelas instituições que os formam e aperfeiçoam.

Ao regressar do Congresso de Cambridge decidi encaminhar-Ihe a mencionada documentação. (*) Apresso-me a fazê-lo estimulado pela notícia publicada pelo "O Globo", em sua edição de 08 do corrente mês, sobre a abertura da Segunda Assembléia sobre Desarmamento das $\mathrm{Na}$ ções Unidas (neste momento em plena realização) informado que o Secretário Geral das $\mathrm{Na}$ ções Unidas, após declarar que "o apocalipse não é mais uma figura bíblica, passou a ser uma possibilidade muito real", pergunta: "Existe, ou não, um fim para esta loucura?

Ernani Braga

Diretor da Escola Nacional de Saúde Pública 